\title{
Phytoplankton taxa, irradiance and nutrient availability determine the seasonal cycle of DMSP in temperate shelf seas
}

\author{
Stephen D. Archer*, Denise G. Cummings, Carole A. Llewellyn, James R. Fishwick \\ Plymouth Marine Laboratory, Prospect Place, Plymouth, Devon PL1 3DH, UK
}

\begin{abstract}
The influences of physico-chemical and biological variables on the concentrations of dimethyl sulphide (DMS) and its precursor $\beta$-dimethylsulphoniopropionate (DMSP) were investigated through an annual cycle in the temperate shelf seas of the western English Channel. Total DMSP to chlorophyll a ratios (DMSPt/chl a) varied seasonally by 40-fold, and DMS and DMSP concentrations became temporally uncoupled, with elevated relative DMS concentrations during spring and midsummer. Taxonomic succession of high DMSP-producing phytoplankton, including Phaeocystis pouchetii, Scrippsiella trochoidea and Prorocentrum minimum, is apparent in the seasonal pattern of DMSPt concentrations. Peridinin and DMSPt concentrations showed similar seasonal trends $(\mathrm{p}<$ 0.0001), illustrating the substantial contribution by dinoflagellate taxa to DMSP production. Summertime stratification of the water column coincided with increased mixed layer doses of photosynthetically active radiation (PAR), increased surface ultraviolet-B (UVB) irradiance relative to PAR and a decrease in nitrate and phosphate availability. PAR dose explained $68 \%$ of the variability in DMSP/chl $a$ during the seasonal study; whilst nitrate concentrations were inversely related to DMSP/chl $a$ and explained $64 \%$ of the variability in log-transformed DMSP/chl a. PAR dose explained only $25 \%$ of the variation in DMS concentration, whilst nitrate concentration was inversely related to DMS and explained $49 \%$ of the variation in log-transformed DMS concentration. The highly significant relationship between DMSP/chl a and PAR dose was similar to those observed for the chlorophyll-specific accumulation of the photoprotective xanthophyll compounds diadinoxanthin and diatoxanthin and the chlorophyll-specific concentrations of UV-absorbing mycosporine-like amino acids. These results lend further, indirect evidence for a photoprotective role of DMSP, possibly associated with physiological stress caused by high PAR and UV radiation and intensified by nutrient limitation.
\end{abstract}

KEY WORDS: DMSP $\cdot$ DMS $\cdot$ Seasonal cycle $\cdot$ Xanthophyll pigments $\cdot$ MAAs $\cdot$ Nutrients

Resale or republication not permitted without written consent of the publisher

\section{INTRODUCTION}

Emission of dimethyl sulphide (DMS) from the oceans may contribute to the nucleation and growth of aerosol particles, enhancing formation of cloud condensation nuclei $(\mathrm{CCN})$ in the marine boundary layer and, thereby, increasing the Earth's albedo (Shaw 1983, Charlson et al. 1987). Once in the atmosphere, the oxidation pathway of DMS is likely to influence the link between DMS and CCN formation. This includes possible reactions with the photolysis products of bio- genic halocarbons, and the presence of pre-existing sea-salt and organic aerosol particles (O'Dowd et al. 2002, von Glasow \& Crutzen 2004, Leck \& Bigg 2005). DMS is generally supersaturated in oceanic waters, and its sea to air flux is dictated to a large extent by seawater surface concentration and the gas transfer velocity. DMS is a product of the enzymatic cleavage of the S-containing osmolyte $\beta$-dimethylsulphoniopropionate (DMSP), synthesised by a variety of phytoplankton (Challenger \& Simpson 1948, Keller et al. 1989). Intracellular concentrations of DMSP in phytoplankton 
vary by $>3$ orders of magnitude (Keller et al. 1989), and the ability to convert DMSP into DMS through DMSPlyase activity also varies markedly between phytoplankton taxa (Niki et al. 2000). DMSP appears to play a range of roles in phytoplankton, in addition to acting as an osmolyte or compatible solute (Stefels 2000). Which physiological function(s) drive(s) the taxonomic variation in DMSP intracellular content remains unclear and is one of the hurdles to the development of mechanistic models that are capable of predicting DMS emission both seasonally and regionally.

Studies of seasonal variations in DMS and DMSP concentrations have played an important part in helping to elucidate some of the important factors controlling DMS emissions. Leck et al. (1990) demonstrated the lack of a relationship between DMS concentrations and phytoplankton biomass or primary production during an annual cycle in the Baltic Sea. They illustrated that variations in DMS concentration must be considered a result of complex physiological and ecological interactions. Studies in both temperate (Kwint \& Kramer 1996) and subtropical (Dacey et al. 1998) waters have found that the seasonal trends in DMS concentrations can become decoupled from the temporal changes in DMSP concentrations. Recently, the daily ultraviolet (UV) radiation dose has been shown to statistically explain $>77 \%$ of the variability in the mixed-layer DMS concentrations in the BATS (Bermuda Atlantic Time-Series Study) data set (Toole \& Siegel 2004) and may be a key to understanding the seasonal variations in the ratio of DMS to DMSP. Similarly, the solar radiation dose (SRD), calculated from the full spectrum of surface irradiance and an extinction coefficient for photosynthetically active radiation (PAR, 400 to $700 \mathrm{~nm}$ ), explained a high proportion of the variance in DMS concentrations measured at BATS (Vallina \& Simó 2007).

Why UV radiation and SRD should positively correlate with DMS concentrations in natural waters remains uncertain. High light and, in particular, UV radiation are thought to have an impact on DMS concentrations through a number of opposing processes. Photolysis of DMS can be a substantial removal process (e.g. Kieber et al. 1996) and is primarily driven by UV radiation. UV radiation also has impacts on the bacterial metabolism of DMSP and DMS (Slezak et al. 2001, Toole et al. 2006). Levels of UV radiation appear to affect the degree of intracellular DMSP accumulation in the few phytoplankton taxa that have been tested under laboratory culture conditions. In the prymnesiophyte Emiliania huxleyi, cells exposed to short-term $(<1 \mathrm{~d})$, elevated levels of UV increased DMSP intracellular concentrations by approximately $20 \%$ (Slezak \& Herndl 2003) and almost 100\% (Sunda et al. 2002), compared to cells exposed to PAR alone. In contrast, exposure to UV at levels sufficiently high to cause unbalanced growth in E. huxleyi had no impact on the intracellular concentration of DMSP (Van Rijssel \& Buma 2002).

Nutrient availability may also play a role in explaining seasonal and geographic variations in the relative production of DMSP and DMS. Differing nutrient regimes support contrasting phytoplankton communities, which may, in part, explain variations in DMS/chlorophyll a (chl a) and DMSP/chl a ratios between eutrophic and oligotrophic waters (Sunda \& Hardison 2008). However, physiological responses of individual taxa of phytoplankton to nutrient availability may have an equally large impact on DMSP and DMS concentrations. Nitrogen limitation caused almost a doubling in intracellular DMSP concentration in Emiliania huxleyi and a 30-fold increase in the diatom Thalassiosira pseudonana (Keller et al. 1999). Furthermore, under nitrogen-limiting conditions, the potential activity of DMSP-lyase enzymes increased in E. huxleyi, possibly explaining a corresponding increase in DMS release from cells compared to a nitrogen-sufficient culture (Sunda et al. 2007).

Increased intracellular DMSP accumulation and DMS production in the face of high light or UV and nutrient limitation are thought to reflect the antioxidant role of DMSP, possibly contributing to the relief of photo-oxidative stress (Sunda et al. 2002). Alternatively, enhanced production of DMSP and DMS under conditions that promote physiological stress may stem from the role of DMSP as a 'secondary metabolite' (Kirst 1996, Stefels 2000). DMSP and its conversion to DMS may act as an overflow mechanism to regulate intracellular sulphur- and nitrogen-containing amino acid proportions or as a means of dissipating excess carbon production (Stefels 2000). There is mounting evidence that DMS release from phytoplankton as a consequence of the physiological role(s) of DMSP and DMS may make a substantial contribution to DMS production in natural waters (Archer 2007). In a seasonal study in the north-western Mediterranean, increased yields of DMS production from DMSP during the summer months were attributed to physiological release from phytoplankton (Vila-Costa et al. 2008). However, a clear understanding and direct physiological evidence for either the putative antioxidant role or for the proposed metabolic overflow mechanism are lacking.

One approach to understanding the roles of DMSP and DMS is to compare their production rates to those of compounds with well-defined physiological roles. Phytoplankton possess a variety of strategies to accommodate the conflicting requirements of absorbing adequate radiation to drive photosynthesis in a highly variable light and nutrient environment and the potentially harmful effects of absorbing too much radiation, which may lead to production of reactive oxygen spe- 
cies (ROS). Excess energy absorbed by light harvesting complexes may be dissipated through the reactions of the xanthophyll cycle pigments, in order to prevent photoinhibition and ROS formation. The major groups of eukaryotic phytoplankton convert the mono-epoxide xanthophyll pigment diadinoxanthin (Dd) to a deepoxide form, diatoxanthin (Dt), as a mechanism to dissipate excess energy (Arsalane et al. 1994). High levels of UV radiation in near-surface waters may exacerbate ROS production by preventing the utilisation of electrons generated through photosynthesis by damaging enzymes of the electron transfer chain and the reaction centre in Photosystem II and through damage to DNA and RNA (reviewed in Davidson 2006). As one of a range of strategies to prevent UV damage, phytoplankton synthesise UV-absorbing compounds, consisting primarily of mycosporine-like amino acids (MAAs) (Hannach \& Sigleo 1998, Neale et al. 1998).

The current study presents a high temporal resolution, seasonal study of the DMS and DMSP concentrations in temperate shelf seas. The study site is characterised by a high degree of variability in physical forcing and biological productivity throughout the year and by a relatively consistent pattern of phytoplankton taxonomic succession (Holligan \& Harbour 1977). In order to improve understanding of the functional roles of DMSP and DMS, the present study aimed to: (1) determine the extent and patterns of seasonal variation in DMS and DMSP concentrations, in relation to changing physico-chemical forcing; (2) determine how these concentrations vary in relation to phytoplankton abundance and taxonomy; and (3) compare the seasonal patterns of DMSP and DMS with the concentrations of photoprotective xanthophyll cycle pigments and UV-absorbing MAAs, in relation to irradiance levels.

\section{MATERIALS AND METHODS}

Time-series site and sampling. Longterm, weekly monitoring of a range of physical, chemical and biological parameters has been carried out at Station (Stn) L4 since 1988 (www.pml.ac.uk/ L4). Stn L4 is located in the western English Channel, at $50^{\circ} 15^{\prime} \mathrm{N}, 04^{\circ} 13^{\prime} \mathrm{W}, 10 \mathrm{~km}$ offshore and in approximately $55 \mathrm{~m}$ of water (Fig. 1). Sampling was carried out at approximately weekly intervals from March 2003 to April 2004, weather permitting. As part of the long-term monitoring programme at L4, single samples were routinely collected at $10 \mathrm{~m}$ depth in a 101 Niskin bottle for nutrient analysis, pigment concentrations, MAA concentrations and phytoplankton abundance. As the mixed-layer depth (MLD) is generally deeper than $10 \mathrm{~m}$ at Stn L4, including on all dates in the present study, all samples were considered to be from the upper mixed layer.

Water column characteristics. A part of the regular Stn L4 sampling programme included deployment of an optical rig on which a Sea Bird 19+ CTD (Serial Numbers: 4180 and 4307) was mounted. A fast repetition rate fluorometer (FRRF; Chelsea Technologies Ltd. FAST ${ }^{\text {tracka }}$ ) was deployed horizontally on the top of the optics rig with a depth sensor and a $2 \pi$ PAR sensor (400 to $700 \mathrm{~nm}$ ).

Nutrient concentrations were determined in samples that were frozen at $-20^{\circ} \mathrm{C}$ and stored for later analysis. Nitrate and phosphate concentrations were determined by colorimetric auto-analysis (Woodward \& Rees 2001), with detection limits of 0.05 and $0.02 \mu \mathrm{M}$, respectively.

DMSP and DMS concentrations. Seawater was collected from the surface using a stainless steel bucket and from $10 \mathrm{~m}$ using a $10 \mathrm{l}$ Niskin bottle on a rosette sampler. Samples were stored in the dark in acid-

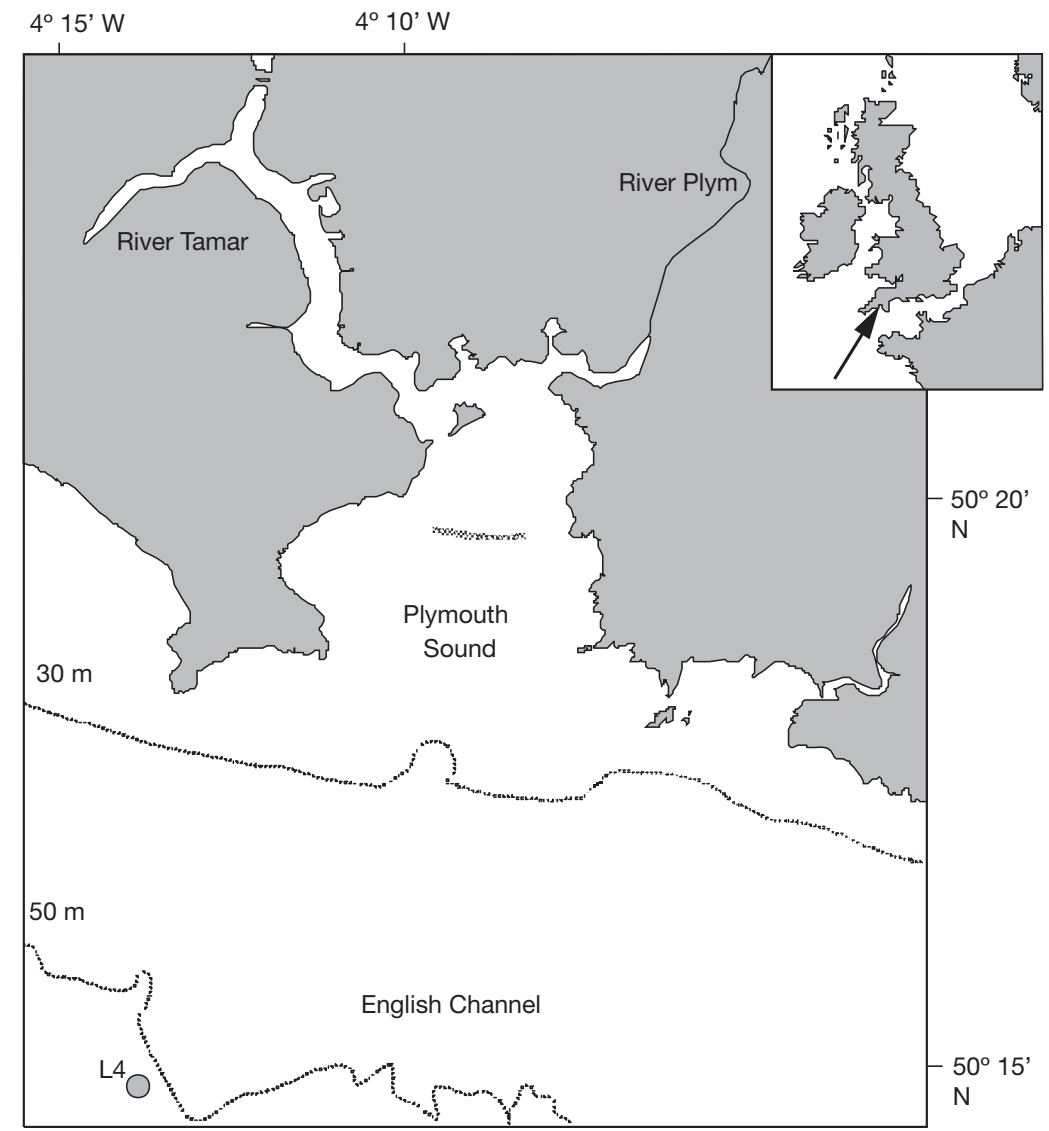

Fig. 1. Location of the time-series sampling station (Stn L4) 
cleaned glass bottles sealed with ground glass stoppers with no headspace. The bottles were kept in a cool box through which seawater at ambient temperature was pumped and were processed immediately on returning to the laboratory within $2 \mathrm{~h}$ of collection. A cryogenic purge-and-trap/gas chromatography system was used to determine DMS and DMSP concentrations. In order to measure DMS concentrations, $10 \mathrm{ml}$ samples were gravity filtered through a $25 \mathrm{~mm} \mathrm{GF} / \mathrm{F}$ filter into a narrow glass vial avoiding any droplet formation, and $5 \mathrm{ml}$ was immediately transferred from the bottom of the vial to a purge tower in order to reduce potential gas exchange. To quantify DMS concentrations, the filtrate was sparged in a stream of nitrogen and the purge gas trapped at $-160^{\circ} \mathrm{C}$ in a Teflon loop. The filter and sparged filtrate were retained for determination of particulate DMSP and dissolved DMSP concentrations following alkaline hydrolysis to DMS in sealed glass vials in $0.5 \mathrm{M} \mathrm{NaOH}$. Recent evidence indicates that even when gentle filtration techniques are used, leakage of DMSP from cells is likely to occur (Kiene \& Slezak 2006). In order to provide a more accurate measurement, the dissolved and particulate DMSP concentrations determined from each filtered sample are presented as a combined total DMSP concentration (DMSPt). A Varian 3800 gas chromatograph equipped with a pulsed flame photometric detector (PFPD) and a Varian $30 \mathrm{~m} \times 0.53 \mathrm{~mm}$ CP Sil 5CB column was used to analyse the trapped gas. DMS standards for calibration were prepared from DMSP-HCl (>98\% purity, CASS, University of Groningen) in a $0.5 \mathrm{M} \mathrm{NaOH}$ solution in Milli-Q water. For this system, analytical precision (\% SD) is typically better than $5 \%$ for DMS and DMSP standards. Analytical error and sample variability were tested on occasion by collecting 3 samples from the same depth. For instance, the coefficients of variation, which incorporated both analytical error and sample difference, for 3 samples collected from the same depth on 12 and 19 May 2003, were 7.1 and $7.5 \%$ for DMS and 2.1 and $2.3 \%$ for DMSPt.

Pigment and MAA concentrations. Pigment and MAA concentrations were determined in $1 \mathrm{l}$ volumes that were separately vacuum filtered to retain phytoplankton on $25 \mathrm{~mm}$ GF/F filters, which were stored in liquid $\mathrm{N}_{2}$ until analysis. Pigments were extracted from filtered phytoplankton into $2 \mathrm{ml}$ acetone using an ultrasonic probe $(30 \mathrm{~s}, 50 \mathrm{~W})$. An internal standard of apo-carotenoate (Sigma-Aldrich Company Ltd.) was added to the acetone. Extracts were centrifuged to remove filter and cell debris (5 min at $20 \times g$ ), and pigments were separated by injection onto a reversedphase column (Hypersil $3 \mathrm{~mm}$ C8 MOS-2) with gradient elution, linked to a high-performance liquid chromotograph (HPLC) with a photodiode array (PDA) detector (Agilent 1100 system). Pigments were identified using retention time and spectral matching by PDA detector (Jeffrey et al. 1997), and concentrations were calculated from calibrations using a suite of standards (DHI Water and Environment).

MAAs were extracted from filtered phytoplankton into $2 \mathrm{ml}$ methanol by sonication with an ultrasonic probe $(35 \mathrm{~s}, 50 \mathrm{~W})$. The extracts were incubated at $45^{\circ} \mathrm{C}$ for $2 \mathrm{~h}$ (Tartarotti \& Sommaruga 2002) and then centrifuged ( $5 \mathrm{~min}$ at $20 \times g$ ) to remove cellular debris. The supernatant was injected $(100 \mu \mathrm{l})$ into a HPLC with a Luna (Phenomenex) $5 \mu \mathrm{m} \mathrm{NH} \mathrm{N}_{2}$ column $(250 \times$ $4.6 \mathrm{~mm}$ ). Mobile Phase A comprised $85 \%$ acetonitrile (15\% $1 \mathrm{M}$ ammonium carbonate buffered to $\mathrm{pH} 10)$, and Mobile Phase B comprised $75 \% 1 \mathrm{M}$ ammonium carbonate and $25 \%$ acetonitrile. Each mobile phase was pre-mixed and degassed by gently bubbling with $\mathrm{N}_{2}$ gas for $10 \mathrm{~min}$. The gradient programme was: $100 \%$ A for 10 min and then a linear gradient to $75 \% \mathrm{~B}$ and $25 \%$ A over $35 \mathrm{~min}$ at a flow rate of $1 \mathrm{ml} \mathrm{min}^{-1}$. MAAs were monitored at 330 and $310 \mathrm{~nm}$ using a PDA detector, scanning between 250 and $500 \mathrm{~nm}$. For quantification, pure samples of palythene, shinorine, mycosporine-glycine, palythine and palythinol, previously isolated from culture extracts by preparative HPLC and verified by liquid-chromatography-mass spectrometry, were quantified using published extinction coefficients (Grönginer et al. 2000) and subsequently analysed by analytical HPLC to establish response factors. The response factors were then used to quantify the MAAs in sample extracts.

Phytoplankton abundance. Flow cytometry was used to enumerate nanophytoplankton ( 2 to $20 \mu \mathrm{m}$ in size) in unfixed samples. Flow cytograms of $90^{\circ}$ light scatter, red and orange fluorescence were used to distinguish and enumerate the single cells of the nanophytoplankton population. Larger phytoplankton were identified and enumerated in samples fixed with Lugol's solution using inverted-microscopy techniques (see www.pml.ac.uk/L4 for details).

Irradiance and radiation dose calculations. Surface irradiance was recorded at the ELDONET station (www.eldonet.org) at the University of Plymouth $\left(50^{\circ} 30^{\prime} \mathrm{N}, 04^{\circ} 10^{\prime} \mathrm{W}\right)$. The 3 -channel dosimeter provided data for UVB ( 280 to $315 \mathrm{~nm}$ ), UVA (315 to $400 \mathrm{~nm}$ ) and visible radiation (PAR, 400 to $700 \mathrm{~nm}$ ). Sample collection at Stn L4 occurred between 10:00 and 11:00 h, and the radiation dose was calculated from the $24 \mathrm{~h}$ irradiance data for the date of sampling. Original irradiance data, averaged every minute, were used to calculate an average surface value $\left(\mathrm{W} \mathrm{m}^{-2}\right)$ for each $24 \mathrm{~h}$ period.

Depth-dependent PAR was estimated from the daily average surface value using a diffuse attenuation coefficient for downwelling irradiance $\left(K_{d}\right)$ calculated from the directly measured water-column profile for PAR at each 
sampling time. The average mixed-layer downwelling radiation dose for PAR was determined from depth-dependent light estimates and the MLD, defined as the point at which a $0.8^{\circ} \mathrm{C}$ difference from the sea surface temperature occurred (Kara et al. 2000). centrations remained relatively high $\left(>0.4 \mu \mathrm{mol} \mathrm{l}^{-1}\right)$ until early May, when they dropped to values of $\sim 0.1$ $\mu \mathrm{mol} \mathrm{l}^{-1}$, typical of the stratified summer conditions at L4 (Fig. 2C). Concentrations recovered dramatically to $>0.4 \mu \mathrm{mol} \mathrm{l} \mathrm{l}^{-1}$ again, once the water column stability broke down in mid-August.

\section{RESULTS}

\section{Environmental variables at Stn L4}

Stn L4 experiences a climate typical of northern temperate waters with more than a 30 -fold variation in the average daily solar radiation at the surface between mid-summer and midwinter months and high daily variability as a result of cloud cover. Nearsurface water temperatures did not start to rise above winter levels of 8 to $9^{\circ} \mathrm{C}$ until early May and reached a maximum of approximately $18^{\circ} \mathrm{C}$ in August (Fig. 2A). The water column at L4 shows some stabilisation as water temperatures rise, and varying degrees of stratification occur during the summer months and from year to year. A relatively long period of water column stability occurred during the summer of 2003, with consistent stratification and a MLD of between 10 and $23 \mathrm{~m}$ that lasted from late-May to mid-August (Fig. 2A).

Formation of a mixed layer intensified the levels of PAR experienced by near-surface phytoplankton during summer months (Fig. 2B). Furthermore, when the water column was stabilised, not only were PAR doses elevated, but the relative dose of UVB received by the phytoplankton was likely to have been higher, as indicated by the increased ratio of surface UVB to PAR irradiance (Fig. 2B).

In conjunction with water column stability, nutrient concentrations varied markedly during the year. Nitrate concentrations began to decrease in midFebruary from typical winter values of from 7 to $12 \mu_{\mathrm{mol}} \mathrm{l}^{-1}$ to values below the detection limit of $0.05 \mu \mathrm{mol} \mathrm{l}^{-1}$ by mid-May and remained at low nanomolar concentrations until late-August (Fig. 2C). Phosphate concentrations showed a similar pattern, although con-
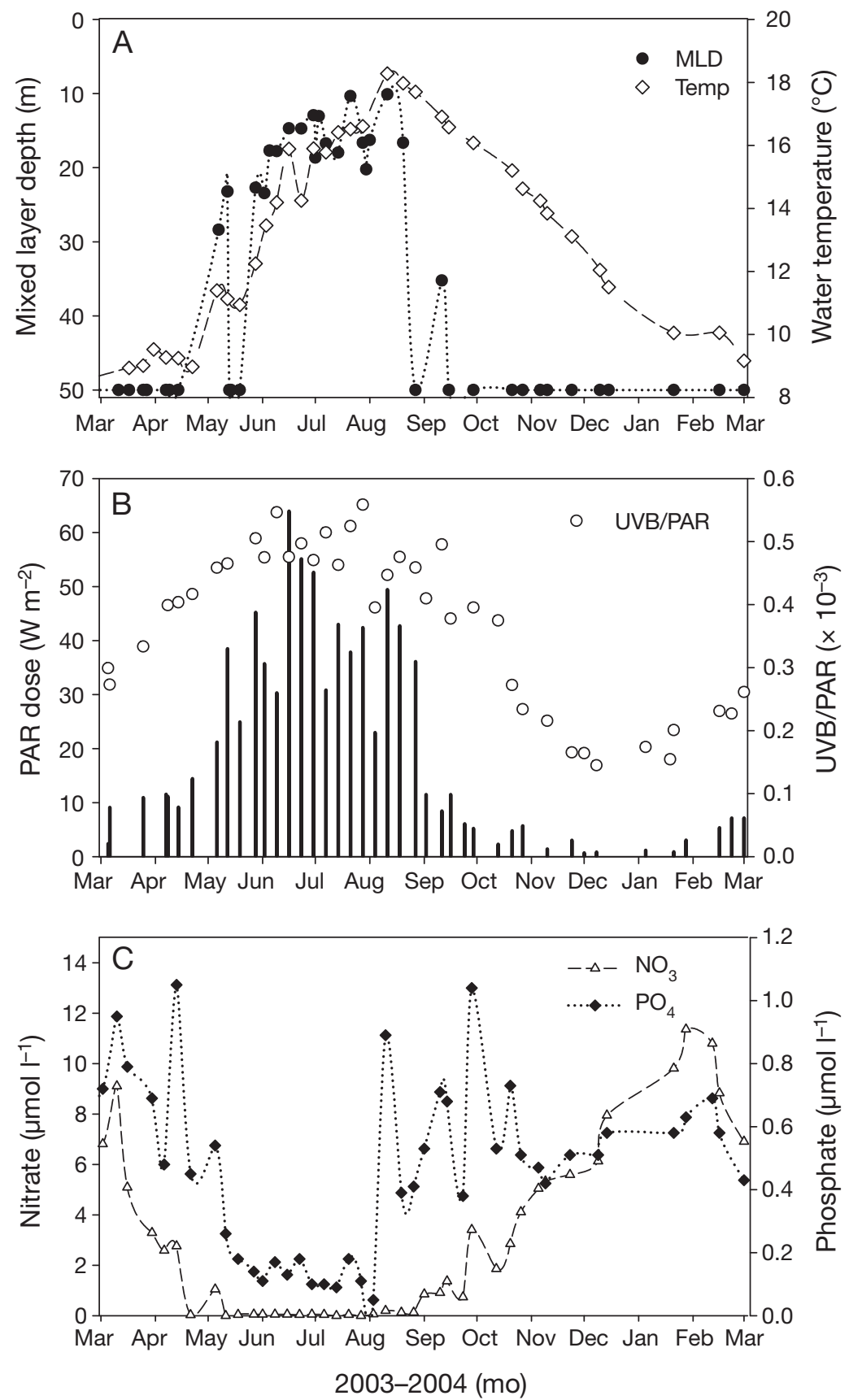

Fig. 2. The physico-chemical environment at Stn L4 during the study period. (A) Mixed layer depth (MLD) calculated according to Kara et al. (2000) and seawater temperature measured at $2 \mathrm{~m}$. (B) Daily average mixed layer PAR dose and the ratio of surface UVB/PAR (ultraviolet-B to photosynthetically active radiation) irradiance, calculated on each sampling day at L4. (C) Con-centrations of nitrate and phosphate measured in samples from $10 \mathrm{~m}$ 


\section{DMS and DMSP concentrations}

Near-surface concentrations of DMSPt ranged from as low as $3 \mathrm{nmol} \mathrm{l}^{-1}$ during winter months to a maximum of $127 \mathrm{nmol} \mathrm{l}^{-1}$ in mid-August (Fig. 3A). An obvious seasonal pattern in the DMSPt concentrations was apparent during the 2003 to 2004 study, which appeared to coincide with the trend in solar radiation and the stability of the water column. An almost continuous increase in DMSPt occurred from late-March through to July. Concentrations remained high during July and August, before they dropped rapidly between late-August and early-September, as stratification of the water column broke down (Fig. 3A).

Average concentrations of DMS in the top $10 \mathrm{~m}$ ranged from $<0.1 \mathrm{nmol}^{-1}$ in mid-winter to $23 \mathrm{nmol} \mathrm{l}^{-1}$ during June 2003 (Fig. 3B). Two periods of high DMS concentration were obvious in the seasonal pattern, the first from late-March to early-May and the second during June. Outside of these periods, even in late summer when DMSPt concentrations were high, DMS concentrations remained $<5 \mathrm{nmol} \mathrm{l}^{-1}$. The 2 peaks in DMS concentration are clear in the seasonal pattern of the DMS/DMSPt ratio, emphasising that elevated DMS concentrations were not simply a product of higher levels of DMSPt (Fig. 3C).

\section{Phytoplankton cell constituents and taxonomy}

As is typical in these waters, the highest chl a concentrations occurred over a short period in spring, reaching $5.5 \mu g \mathrm{l}^{-1}$ in mid-April 2003 (Fig. 4A). During the winter months chl a concentrations varied between 0.5 and $1.0 \mu \mathrm{g} \mathrm{l}^{-1}$. Summer and autumn were characterised by variable concentrations between 1.0 and $3.0 \mu \mathrm{g} \mathrm{l^{-1 }}$, although the lowest of all of the concentrations $\left(0.1 \mathrm{\mu g}^{-1}\right)$ was measured during a period from late-May to early-June, which coincided with the onset of stratification. The ratio of DMSPt (FW 135) to chl a, a proxy for the accumulation of intracellular DMSP relative to light-harvesting capacity, varied seasonally by $>40$-fold, from 0.4 to $27.5 \mathrm{~g} \mathrm{~g}^{-1}$, with the highest values in the mixed layer during summer months (Fig. 4B). Peridinin, a specific marker pigment for Type 1 Dinophyta (Jeffrey \& Wright 2006), varied between undetectable concentrations and $120 \mathrm{ng} \mathrm{l}^{-1}$ (data not shown). The peridinin to chl a ratio was highly variable, ranging from 0 to $0.17 \mathrm{~g} \mathrm{~g}^{-1}$, and showed a similar seasonal trend to that of DMSPt/chl $a$, with highest values during summer months when the water column was stratified and 2 distinct peaks in June and August (Fig. 4B). 19-hexanoyloxyfucoxanthin (19-Hex) is regarded as a marker pigment for Haptophyta, including the DMSPrich taxa Phaeocystis spp. and Emiliania huxleyi, and for some Dinophyta. Concentrations of 19-Hex ranged between 10 and $350 \mathrm{ng} \mathrm{l}^{-1}$, and the 19-Hex to chl a ratio varied between 0.004 and 0.26 (data not shown). However, the seasonal pattern of 19-Hex/chl a showed little similarity to that of DMSP/chl a (Table 1).

The combined concentrations of the xanthophyll pigments Dd and Dt varied throughout the year from 8 to $290 \mathrm{ng} \mathrm{l}^{-1}$. When normalised to $\mathrm{chl} a$, the ratio [(Dd +
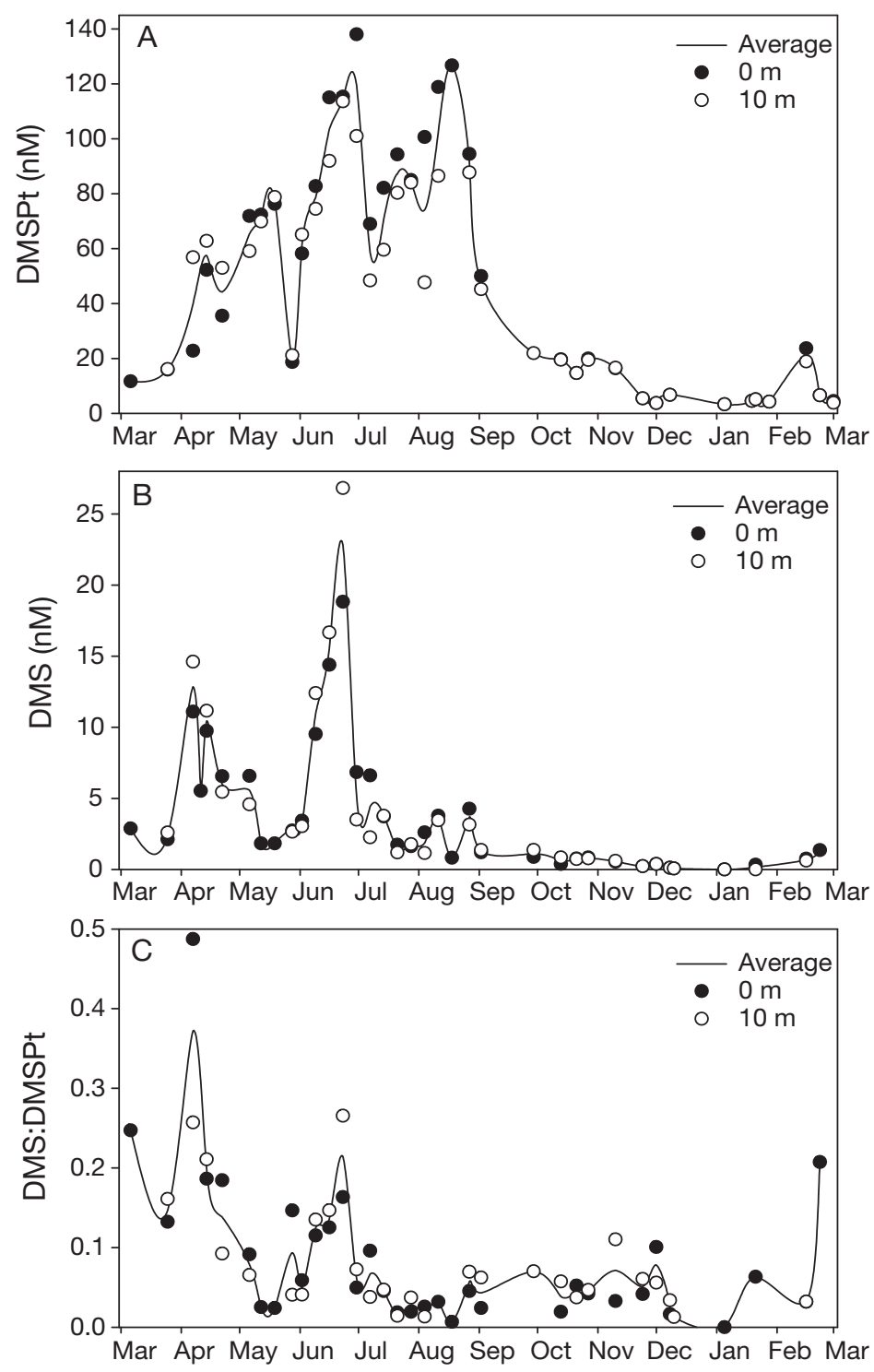

Fig. 3. Seasonal variations in: (A) DMSPt (total $\beta$-dimethylsulphoniopropionate) and (B) DMS (dimethyl sulphide) concentrations measured in the upper $10 \mathrm{~m}$ of the water column at Stn L4. (C) Average molar ratio of DMS/DMSPt. Values were taken from the surface and $10 \mathrm{~m}_{i}$ the line illustrates the average value or the surface value when it was not possible to obtain a $10 \mathrm{~m}$ sample 
$\mathrm{Dt}) / \mathrm{chl}$ a] varied almost 10 -fold between the minimum in October of $0.025 \mathrm{~g} \mathrm{~g}^{-1}$ and a summer maximum in July of $0.228 \mathrm{~g} \mathrm{~g}^{-1}$ (Fig. 4C). In broad terms, the seasonal trend in $\mathrm{Dd}+\mathrm{Dt}$ resembled that of chl $a$, but with generally reduced xanthophyll cycle pigment concentrations relative to chl $a$ in spring and autumn compared to the period of maximum irradiance in summer (Fig. 4C).

MAAs were present throughout the 2003 to 2004 study period at L4, and their combined concentrations showed a similar seasonal pattern to that observed in 1998 (Llewellyn \& Harbour 2003). The total quantified MAA concentrations varied from 1 to $350 \mathrm{ng} \mathrm{l}^{-1}$ and were dominated by shinorine, mycosporine glycine and porphyra-334, with additional contributions from palythenic acid, palythene, palithine and an unidentified compound. The MAA/chl a ratio varied $>20$-fold, remaining below $0.01 \mathrm{~g} \mathrm{~g}^{-1}$ from the end of August to the end of March, whilst values $>0.05 \mathrm{~g} \mathrm{~g}^{-1}$ were restricted to June and early July and a peak in August (Fig. 4C).

\section{Contributors to DMSP standing stocks}

Chl $a$ and DMSPt showed no significant relationship, suggesting that as seasonal taxonomic succession occurred, the relative investment in chlorophyll $a$ and DMSP accumulation altered (Table 1). An indication of the components of the phytoplankton communities responsible for DMSP production can be gained from the combination of phytoplankton abundance (www.pml.ac.uk/L4) and the concentrations of marker pigments. Nanophytoplankton abundance showed a similar seasonal pattern and significant relationship to DMSPt (Fig. 5A, B, Table 1), suggesting this component of the phytoplankton contributed substantially to DMSP production. In common with other years, Phaeocystis pouchetii occurred in relatively high abundance from mid-March to late April in the western English Channel. Based on a cell content of $2 \mathrm{pg}$ DMSP cell ${ }^{-1}$ for P. globosa (Stefels \& van Boekel 1993) and assuming similar DMSP cell content in the 2 species, $P$. pouchetii accounted for an estimated 40 to $60 \mathrm{nmol} \mathrm{l}^{-1}$ DMSPt during this time (Fig. 6A). This contribution by $P$. pouchetii may be an underestimate, as the low volumes analysed for flow cytometric cell counting are likely to underestimate the abundance of colonial P. pouchetii cells, possibly explaining the dif-
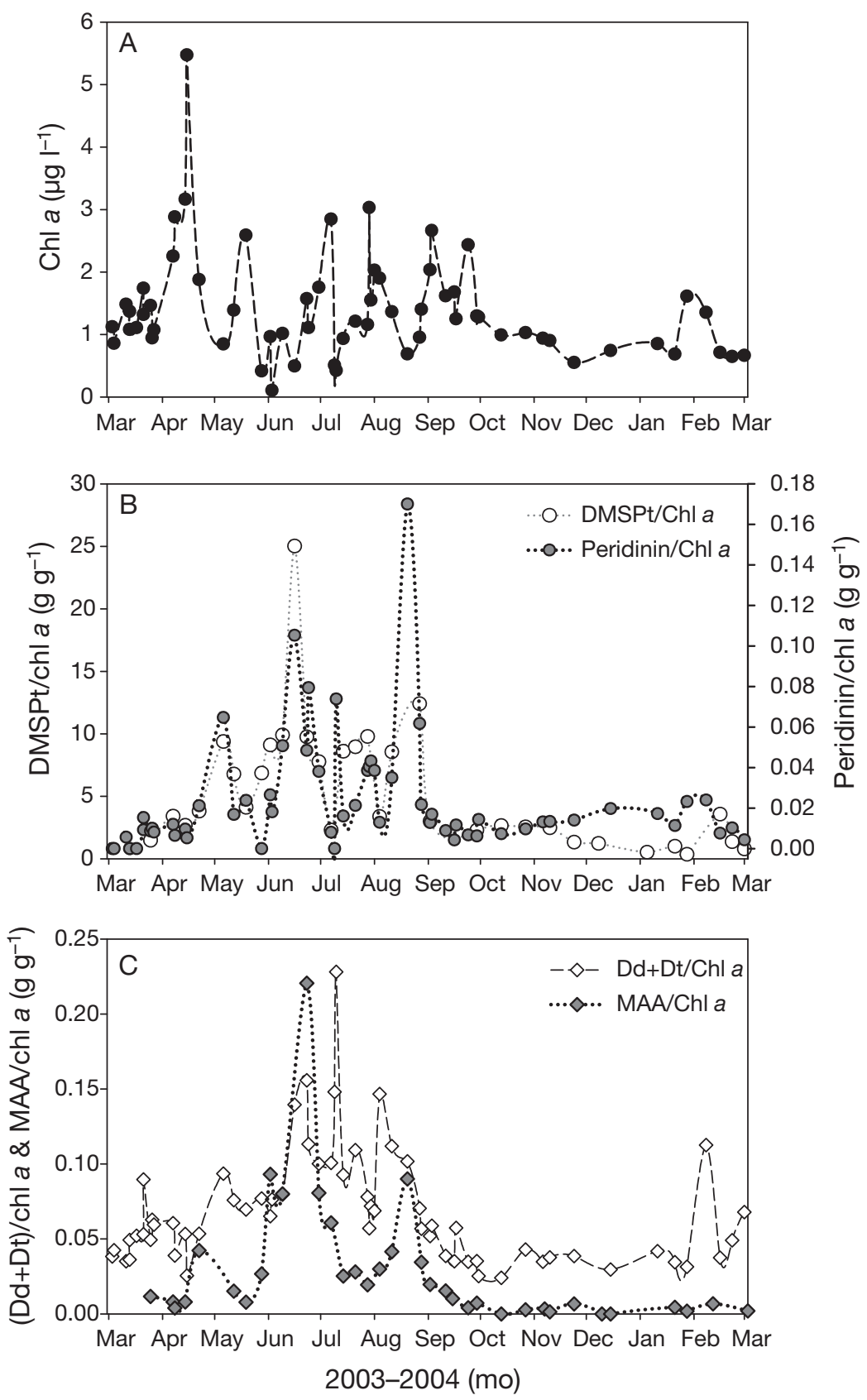

Fig. 4. Seasonal variations at Stn L4 in: (A) chlorophyll a (chl a) concentration, (B) DMSPt measured at $10 \mathrm{~m}$ to chl $a$ and peridinin to chl $a$. (C) Ratios of the combined xanthophyll cycle pigments diadinoxanthin (Dd) and diatoxanthin (Dt) to chl $a$ and micosporine-like amino acids (MAA) to chl a

ference between derived and observed DMSPt concentrations. Lithed Emiliania huxleyi occurred sporadically throughout the summer months, but at low concentrations of $\leq 250$ cells $\mathrm{ml}^{-1}$. At these abundances, E. huxleyi would contribute $<2$ nmol DMSPt $1^{-1}$, assuming a cell content of $1 \mathrm{pg}$ DMSP cell ${ }^{-1}$ (Keller et al. 1989). It is possible that non-lithed life stages of E. huxleyi were more abundant, but were not possible 
Table 1. Least-squares, linear regression analyses $(y=a x+b)$ between seasonally varying parameters measured at Stn L4; for nitrate and phosphate, $y=a \ln (x)+b$. Values of the relationships shown in Figs. 5 to 8 are included. p: the level of significance in the analysis of variance; NS: value not significant, $p>0.05$; superscript a: the average value of measurements at 0 and $10 \mathrm{~m}$; superscript $\mathrm{b}$ : the value measured at $10 \mathrm{~m}_{\text {; }}$ DMSPt: total $\beta$-dimethylsulphoniopropionate; DMS: dimethyl sulphide; Dd + Dt: diadinoxanthin + diatoxanthin; MAA: mycosporine-like amino acids; PAR: photosynthetically active radiation

\begin{tabular}{|c|c|c|c|c|}
\hline & a & $b$ & $\mathrm{r}^{2}$ & $\mathrm{p}$ \\
\hline \multicolumn{5}{|l|}{ Water temperature $\left({ }^{\circ} \mathrm{C}\right)$} \\
\hline DMSPt $\left(\mathrm{nmol} \mathrm{l}^{-1}\right)^{\mathrm{a}}$ & $7.5 \pm 1.9$ & NS & 0.35 & 0.0006 \\
\hline $\operatorname{DMS}\left(\mathrm{nmol} \mathrm{l}^{-1}\right)^{\mathrm{a}}$ & NS & NS & 0.00 & 0.83 \\
\hline DMSPt/chl a $\left(\mathrm{g} \mathrm{g}^{-1}\right)^{\mathrm{b}}$ & $0.72 \pm 0.30$ & NS & 0.17 & 0.025 \\
\hline \multicolumn{5}{|l|}{ Chlorophyll a $\left(\mathrm{ng} \mathrm{l}^{-1}\right)^{\mathrm{b}}$} \\
\hline DMSPt $\left(\mathrm{ng} \mathrm{l}^{-1}\right)^{\mathrm{b}}$ & NS & NS & 0.12 & 0.06 \\
\hline DMS $\left(\mathrm{ng} \mathrm{l}^{-1}\right)^{\mathrm{b}}$ & NS & NS & 0.06 & 0.22 \\
\hline $\mathrm{Dd}+\mathrm{Dt}\left(\mathrm{ng} \mathrm{l}^{-1}\right)^{\mathrm{b}}$ & $0.042 \pm 0.007$ & $30 \pm 12$ & 0.36 & $<0.0001$ \\
\hline MAA $\left(\mathrm{ng} \mathrm{l}^{-1}\right)^{\mathrm{b}}$ & $0.019 \pm 0.009$ & NS & 0.12 & 0.04 \\
\hline \multicolumn{5}{|l|}{ DMSPt $\left(\mathrm{ng} \mathrm{l}^{-1}\right)^{\mathrm{b}}$} \\
\hline $\mathrm{Dd}+\mathrm{Dt}\left(\mathrm{ng} \mathrm{l}^{-1}\right)^{\mathrm{b}}$ & $0.009 \pm 0.002$ & $37 \pm 8$ & 0.37 & 0.0001 \\
\hline MAA $\left(\mathrm{ng} \mathrm{l}^{-1}\right)^{\mathrm{b}}$ & $0.010 \pm 0.003$ & NS & 0.39 & 0.0002 \\
\hline \multicolumn{5}{|l|}{ Nanophytoplankton (cells ml $\left.\mathrm{ml}^{-1}\right)^{\mathrm{a}}$} \\
\hline DMSPt (pg ml $\left.{ }^{-1}\right)^{\mathrm{a}}$ (Fig. 5) & $2.7 \pm 0.4$ & $1520 \pm 780$ & 0.67 & $<0.0001$ \\
\hline \multicolumn{5}{|l|}{ Peridinin $\left(\mathrm{ng} \mathrm{l}^{-1}\right)^{\mathrm{b}}$} \\
\hline DMSPt (ng l-1 $)^{\mathrm{b}}$ (Fig. 6) & $186 \pm 22$ & $1030 \pm 790$ & 0.71 & $<0.0001$ \\
\hline $\mathrm{Dd}+\mathrm{Dt}\left(\mathrm{ng} \mathrm{l}^{-1}\right)^{\mathrm{b}}$ & $1.10 \pm 0.24$ & $58 \pm 9$ & 0.25 & 0.001 \\
\hline MAA $\left(\mathrm{ng} \mathrm{l}^{-1}\right)^{\mathrm{b}}$ & $0.17 \pm 0.07$ & NS & 0.16 & 0.018 \\
\hline \multicolumn{5}{|c|}{ 19-Hexanoyloxyfucoxanthin $\left(\mathrm{ng} \mathrm{l}^{-1}\right)^{b}$} \\
\hline DMSPt $\left(\mathrm{ng} \mathrm{l}^{-1}\right)^{\mathrm{b}}$ & $30 \pm 9$ & NS & 0.25 & 0.003 \\
\hline \multicolumn{5}{|l|}{ PAR dose $\left(\mathrm{W} \mathrm{m}^{-2}\right)$} \\
\hline DMSPt/chl a $\left(\text { g g }^{-1}\right)^{b}$ (Fig. 7) & $0.21 \pm 0.03$ & NS & 0.68 & $<0.0001$ \\
\hline DMS (nmol 1-1 $)^{\mathrm{a}}$ (Fig. 7) & $0.13 \pm 0.04$ & NS & 0.25 & 0.002 \\
\hline DMS/DMSPt $\left(\mathrm{mol} \mathrm{mol}^{-1}\right)^{\mathrm{a}}$ & NS & 0.11 & 0.01 & 0.60 \\
\hline$(\mathrm{Dt}+\mathrm{Dd}) / \mathrm{chl} a\left(\mathrm{~g} \mathrm{~g}^{-1}\right)^{\mathrm{b}}$ (Fig. 7) & $0.0015 \pm 0.0002$ & $0.037 \pm 0.005$ & 0.66 & $<0.0001$ \\
\hline MAA/chl a $\left(\mathrm{g} \mathrm{g}^{-1}\right)^{\mathrm{b}}$ (Fig. 7$)$ & $0.0017 \pm 0.0003$ & NS & 0.47 & $<0.0001$ \\
\hline Peridinin/chl a $\left(\mathrm{g} \mathrm{g}^{-1}\right)^{\mathrm{b}}$ & $0.0066 \pm 0.0028$ & NS & 0.15 & 0.02 \\
\hline \multicolumn{5}{|l|}{ Nitrate $(\mu \mathrm{M})^{b}$} \\
\hline Ln(DMSPt/chl a) $\left(\mathrm{g} \mathrm{g}^{-1}\right)^{\mathrm{b}}$ (Fig. 8) & $-0.23 \pm 0.03$ & $1.9 \pm 0.1$ & 0.64 & $<0.0001$ \\
\hline Ln(DMS) $\left(\mathrm{nmol} \mathrm{l}^{-1}\right)^{\mathrm{b}}$ & $-0.38 \pm 0.08$ & $1.5 \pm 0.3$ & 0.49 & $<0.0001$ \\
\hline $\mathrm{Ln}(\mathrm{DMS} / \mathrm{DMSPt})\left(\mathrm{mol} \mathrm{mol}^{-1}\right)^{\mathrm{b}}$ & NS & NS & 0.00 & 0.39 \\
\hline $\operatorname{Ln}[(\mathrm{Dd}+\mathrm{Dt}) / \mathrm{chl} \mathrm{a}]\left(\mathrm{mg} \mathrm{g}^{-1}\right)^{\mathrm{b}}$ & $-0.12 \pm 0.02$ & $11.5 \pm 0.1$ & 0.26 & 0.0005 \\
\hline Ln(Peridinin/chl a) $\left(\mathrm{mg} \mathrm{g}^{-1}\right)^{\mathrm{b}}$ & $-0.11 \pm 0.05$ & $3.0 \pm 0.2$ & 0.12 & 0.03 \\
\hline \multicolumn{5}{|l|}{ Phosphate $(\mu \mathrm{M})^{b}$} \\
\hline Ln(DMSPt/chl a) $\left(\mathrm{g} \mathrm{g}^{-1}\right)^{\mathrm{b}}$ & $-1.61 \pm 0.001$ & $2.0 \pm 0.3$ & 0.22 & $<0.008$ \\
\hline $\operatorname{Ln}(\mathrm{DMS})\left(\mathrm{nmol} \mathrm{l}^{-1}\right)^{\mathrm{b}}$ & NS & NS & 0.04 & 0.30 \\
\hline
\end{tabular}

to discriminate from the general nanophytoplankton population. However, there was only a marginally significant relationship between DMSPt and 19-Hex on a seasonal basis (Table 1).

In contrast, concentrations of peridinin explained $71 \%$ of the variability in DMSPt concentrations (Fig. 6B, Table 1). Abundant dinoflagellate taxa that were identified included Karenia mikimotoi, which occurred at highest concentrations of $\sim 100$ cells $\mathrm{ml}^{-1}$ during a $2 \mathrm{wk}$ period in late June to early July.
Although this coincided with a peak in DMSPt (Fig. 6), measured intracellular concentrations of $K$. mikimotoi (= Gyrodinium aureolum) are low (<1 pg DMSP cell ${ }^{-1}$ ) amongst the Dinophyta (Keller et al. 1989). On the other hand, the dinoflagellate Scrippsiella trochoidea, which occurred at abundances approaching 25 cells $\mathrm{ml}^{-1}$ and may contain as much as 380 pg DMSP cell ${ }^{-1}$ (Keller et al. 1989), may have contributed to the bulk of the DMSPt at this time (Fig. 6). The DMSP-rich dinoflagellate Prorocentrum minimum occurred at concentrations reaching 500 cells $\mathrm{ml}^{-1}$ during August and, based on a cell content of $20 \mathrm{pg}$ DMSP cell ${ }^{-1}$ (Keller et al. 1989), may have made up the major part $(\sim 60 \%)$ of the peak in DMSPt at that time (Fig. 6). The strong relationships between DMSPt, nanophytoplankton abundance and peridinin, but not 19-Hex, suggest that a significant proportion of the nanophytoplankton were dinoflagellate taxa that were not specifically identified in the microscope analyses, possibly due to their small size.

\section{Environmental forcing and physiological function}

Temperature explained approximately $30 \%$ of the variability in average DMSPt concentrations and the DMSP/chl a ratio in the upper $10 \mathrm{~m}$ at L4 from 2003 to 2004 (Table 1). DMS concentrations showed no significant relationship to water temperature.

DMSPt/chl a was considerably more sensitive to seasonal changes in the light environment experienced by the phytoplankton community at L4, showing a highly significant relationship $\left(\mathrm{r}^{2}=0.68, \mathrm{p}<\right.$ 0.0001 ) to PAR dose (Fig. 7A, Table 1). DMS concentrations also showed a significant relationship to PAR dose, but at a lower level of significance than that observed for DMSPt/chl a (Fig. 7B, Table 1).

That the relationship between DMSPt/chl $a$ and PAR dose is linked photophysiologically to the role of DMSP is supported by the similar level of significance seen between $(\mathrm{Dt}+\mathrm{Dd}) / \mathrm{chl} \mathrm{a}$ and PAR dose and between MAA/chl $a$ and PAR dose (Fig. 7C, D, Table 1). 
Although DMSPt/chl $a_{1}(\mathrm{Dd}+\mathrm{Dt}) / \mathrm{chl} a$ and $\mathrm{MAA} / \mathrm{chl}$ a were clearly closely related to PAR dose (Fig. 7), DMSPt concentrations explained only 37 and $39 \%$ of the variability in Dd + Dt and MAA concentrations (Table 1). This may be a product of the high variability in all 3 parameters during the months when water column stratification occurred, illustrated in the chl a-normalised concentrations (Fig. 4).

Nitrate concentrations showed a non-linear, inverse relationship to DMSP/chl $a$ and DMS with particularly high variability in DMSP/chl $a$ at the lowest nitrate concentrations (Fig. 8) that coincided with stratification of the water column. Taking into account this high variability at low concentrations, nitrate explained 64 and $49 \%$ of the variability in log-transformed DMSP/chl a ratios and DMS concentrations, respectively (Fig. 8, Table 1). More accurate measurements of nitrate concentrations below the detection limit of $0.05 \mu \mathrm{M}$ may have increased the significance of these relationships. Less significant relationships occurred between nitrate concentrations and log-transformed (Dd + Dt)/chl a or peridinin/chl a ratios (Table 1). Phosphate concentrations provided a weaker explanation $(22 \%)$ of seasonal variations in log-transformed DMSP/chl a ratios and showed no significant relationships to DMS concentrations (Table 1).
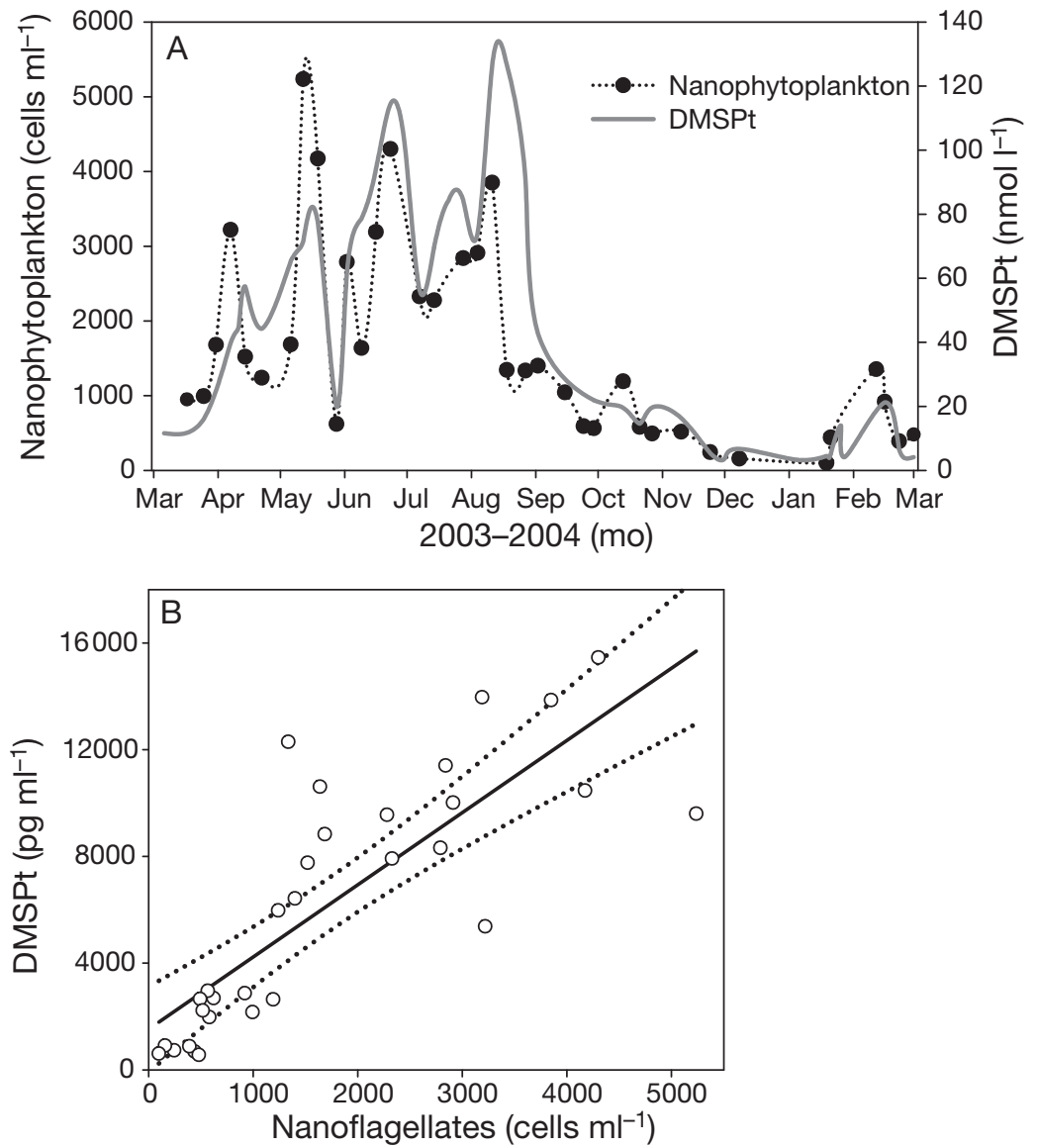

Fig. 5. (A) Seasonal variation at Stn L4 in the abundance of nanophytoplankton quantified by flow cytometry in relation to average DMSPt concentrations. (B) Relationship between nanophytoplankton abundance and DMSPt concentration. The values shown are the average of surface and $10 \mathrm{~m}$ samples

\section{DISCUSSION}

Although seasonal uncoupling between phytoplankton biomass and DMSP and between DMSP and DMS concentrations are considered to be widespread features globally (e.g. Simó \& Pedrós-Alió 1999), these assumptions are based on relatively few comprehensive seasonal observations. The present study illustrates that at a relatively productive, temperate shelf location, DMSP/chl a ratios can vary seasonally by 40 -fold (Fig. 4) and that DMS/DMSP ratios are highly variable, with elevated relative DMS concentrations during spring and mid-summer (Fig. 3). In contrast, DMSP and DMS concentrations were very closely related from May to November in near-shore waters of the Saint Lawrence Estuary, which is located at similar latitude to the western English Channel (Michaud et al. 2007). The difference between these 2 sites may reflect the impact that the seasonal stratification and resulting elevated irradiance levels that occur at Stn L4 has on phytoplankton physiology, in contrast to the more tidally mixed, near-shore environment of the Saint Lawrence Estuary. Similar degrees of uncoupling between DMSP and chl $a$ and between DMSP and DMS to those found in the present study were observed in the seasonal cycle conducted in the oligotrophic Sargasso Sea at BATS (Dacey et al. 1998, Lefèvre et al. 2002). However, the degree to which PAR dose explains the variability in DMS concentrations in the western English Channel (31\%; Table 1) is considerably lower than observed for the relationship between DMS and UV radiation dose (77\%) or monthly average DMS verses solar radiation dose $(81 \%)$ at BATS (Toole \& Siegel 2004, Vallina \& Simó 2007).

Seasonal uncoupling of DMS from DMSP concentrations in the western English Channel, evident as variations in DMS/DMSP (Fig. 3), appears to be partly a consequence of taxonomic succession of eukaryotic phytoplankton. The highly significant relationship between peridinin and DMSPt and the apparently major contribution to the highest peaks in DMSPt concentrations during the year made by Scrippsiella tro- 


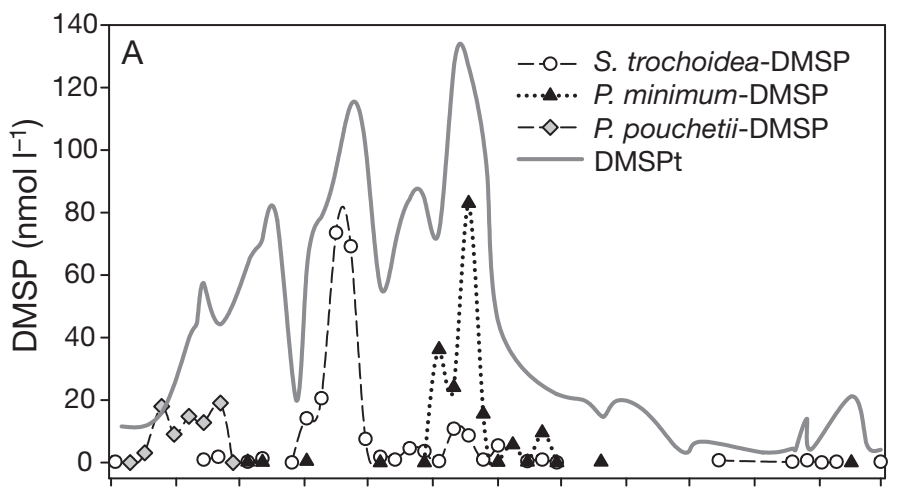

Mar Apr May Jun Jul Aug Sep Oct Nov Dec Jan Feb Mar 2003-2004 (mo)

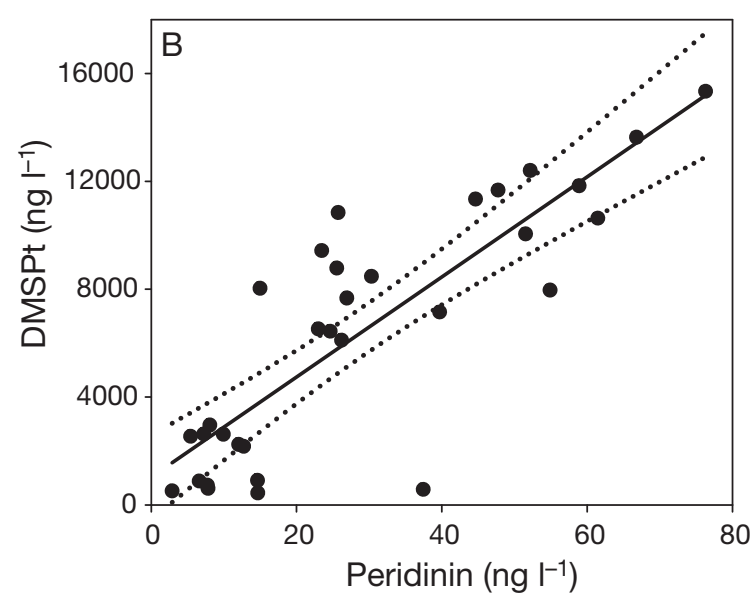

Fig. 6. (A) Contribution of 3 individual taxa (Scrippsiella trochoidea, Prorocentrum minimum, Phaeocystis pouchetii) to DMSPt concentrations in the upper $10 \mathrm{~m}$ at Stn L4. The contribution of each taxon was estimated from cell abundance measured in samples from $10 \mathrm{~m}$ depth and literature values of the DMSP cell content (see 'Results' for details). (B) Relationship between concentrations of peridinin, the marker pigment for Type 1 dinoflagellates, and DMSPt in the upper $10 \mathrm{~m}$ at Stn L4

choidea and Prorocentrum minimum (Fig. 6, Table 1) illustrate the important role that Dinophyta play in DMSP production in this temperate shelf location. However, caution should be applied when estimating the contribution of specific taxa based on literature values of cellular DMSP, as intracellular concentrations have been shown to vary in culture in relation to the nutrient and light environment (Stefels et al. 2007). Despite similar DMSP concentrations attributed to S. trochoidea and P. minimum, substantially higher concentrations of DMS occurred during June/July when $S$. trochoidea was relatively abundant compared to the period in August when P. minimum appeared to dominate DMSP production (Fig. 3). Why so much lower DMS concentrations resulted from DMSP production by $P$. minimum is unclear. Levels of irradiance were similar, and the water column remained stratified
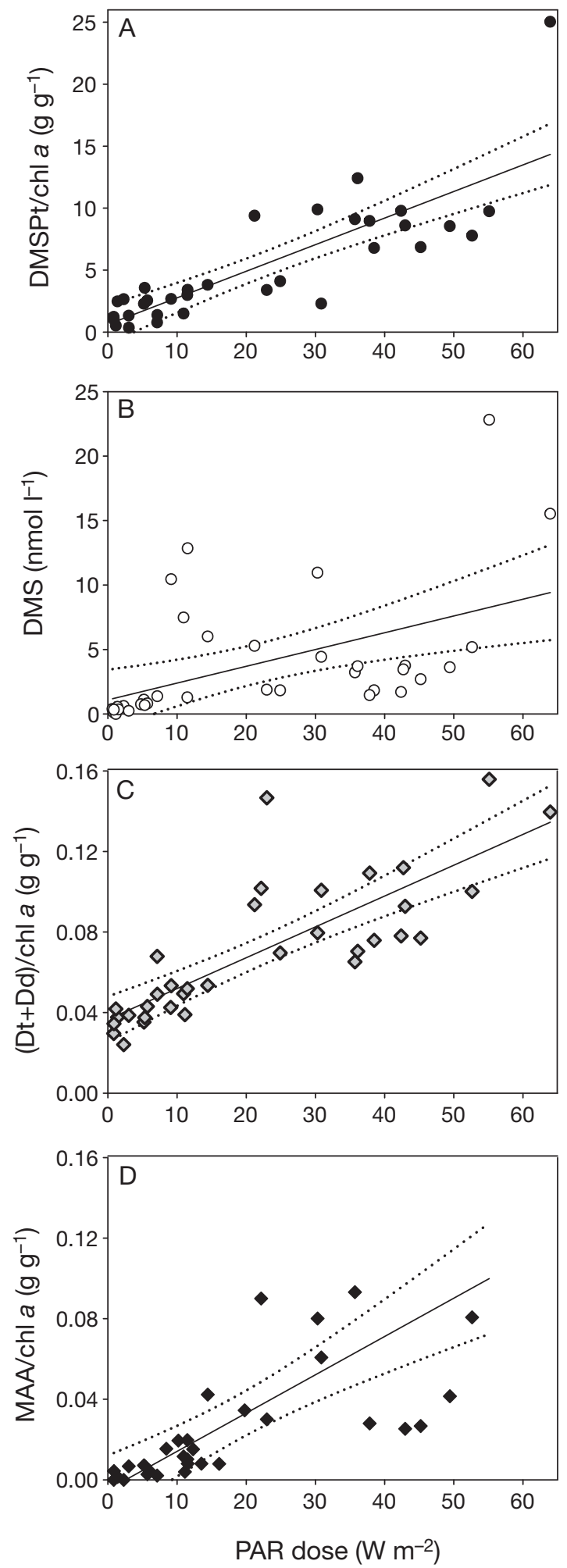

Fig. 7. Relationship between the daily average doses of photosynthetically active radiation (PAR) and (A) DMSPt/chl $a_{1}$ (B) DMS, (C) $(\mathrm{Dd}+\mathrm{Dt}) / \mathrm{chl} a$ and (D) MAA/chl $a$ at Stn L4 during the study period. Details of the linear regressions are given in Table 1. Dotted lines are the $95 \%$ confidence limits 


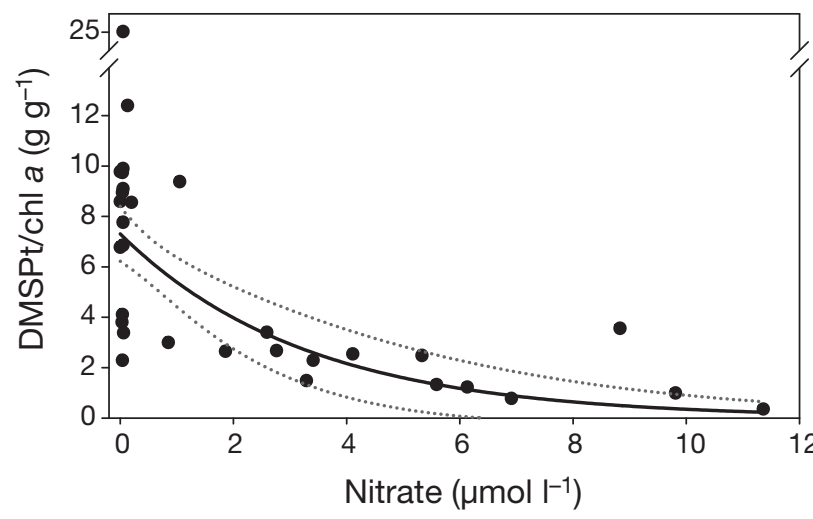

Fig. 8. Relationship between nitrate concentration and $\mathrm{DMSP} / \mathrm{chl} a$ at Stn L4 during the study period. A logarithmic fit to the data is shown, the details of which are given in Table 1. Dotted lines are the $95 \%$ confidence limit

during the occurrence of both species. It is possible that the heterotrophic community may have had differing degrees of requirement for DMSP and DMS, with greater metabolic utilisation of DMS in August, resulting in the low DMS/DMSPt ratio. Alternatively, the 2 dinoflagellate species may utilise DMSP for different physiological functions. S. trochoidea was found to convert dissolved DMSP to DMS at a high rate, suggesting it possesses an active DMSP-lyase capability (Niki et al. 2000), which may account, in part, for the higher DMS concentrations observed in June. Certainly the spring peak in DMSPt concentrations combined with a high DMS/ DMSPt ratio is characteristic of Phaeocystis spp. and may reflect the highly active, extracellular DMSP-lyase that these species seem to possess (Stefels \& van Boeckel 1993). Interestingly, Karenia mikimotoi co-occurred with $S$. trochoidea and at higher abundances, but is considered to be a low producer of DMSP (Keller et al. 1989). Further study of why these 3 dinoflagellate species differ and, in the case of $K$. mikimotoi, whether an alternative strategy to DMSP production occurs may shed more light on the physiological functions of DMSP and its breakdown products.

Mechanistic models that incorporate radiation effects on the parameterisation of DMS cycling processes have shown improved skill at simulating the seasonal patterns of DMS concentrations for the BATS time series (Lefèvre et al. 2002, Toole et al. 2008,Vallina et al. 2008). In both more recent models, the incorporation of a DMS production pathway dependent on UV-driven (Toole et al. 2008) or solar-radiation-driven (Vallina et al. 2008) release of DMS from phytoplankton appeared to be the most important contributing parameterisation to improved simulation of the observed seasonal data set. Justification for the inclusion of light-driven DMS release from phytoplankton in these models stems primarily from evidence that DMSP and its breakdown products may act as antioxidants in phytoplankton (Sunda et al. 2002). The increase in DMSPt/chl $a$ in the face of increased PAR dose and possibly elevated UVB exposure at L4 are consistent with intracellular up-regulation of an antioxidant system in the face of environmental stress and/or selection of algal taxa or strains possessing high intracellular DMSP to minimise levels of oxidative stress. The highly significant relationship between DMSPt/chl $a$ and light levels (Table 1) suggests that a photophysiological function influences the seasonal cycle of DMSP in temperate waters.

The indirect evidence that DMSP has a photophysiological role is strengthened by the observations that the accumulation of photoprotective and UVabsorbing compounds showed a similar response to seasonally varying light fields. The significant relationship between the chlorophyll-specific xanthophyll pigment pool [(Dd + Dt)/chl a] and PAR dose (Fig. 7) illustrates an adaptive requirement for greater capacity to prevent photoinhibition amongst the phytoplankton communities that inhabited the high-irradiance, stratified waters during summer months. Although it is possible that variation in $(\mathrm{Dd}+\mathrm{Dt}) / \mathrm{chl}$ a may reflect taxonomic succession, diadinoxanthin and diatoxanthin are synthesised by a high proportion of the microalgal taxa that dominate the phytoplankton communities at L4, including members of the Bacillariophyta, Haptophyta and Dinophyta (reviewed in Jeffrey \& Wright 2006). Despite the energetically efficient mechanism of recycling of Dt to Dd following de-epoxidation, an increase of the intracellular concentration of xanthophyll pigments appears to be a common longer term response to prevent photoinhibition. Higher intracellular concentrations of the xanthophyll pigments may confer a greater capacity to respond rapidly to fluctuations in light environment (Lavaud et al. 2007), in part reflecting the slower rate of recycling of Dt to Dd compared to the de-epoxidation step. The proposed antioxidant function of DMSP involves irreversible, enzymatic cleavage to DMS, which may be oxidised to dimethyl sulphoxide or to methane sulphinic acid (Sunda et al. 2002). Continuous de novo synthesis of DMSP would be required in the light in order to maintain sufficient intracellular concentrations. This apparently irreversible antioxidant cascade contrasts with the recycling of xanthophyll pigments and may result in the need for greater adaptive variation in intracellular DMSP pools in response to differing exposure to photoinhibitory light levels. This may explain the $\sim 40$-fold variation in DMSP/chl a compared to an only $\sim 10$-fold variation in $(\mathrm{Dd}+\mathrm{Dt}) / \mathrm{chl}$ a observed during the annual cycle at L4 (Fig. 4) and the differences in levels of significance of their relationships to PAR dose (Fig. 7, Table 1). 
MAAs protect cells from damage caused by UV irradiance by absorbing high-energy photons and dissipating the energy as heat. However, evidence from in vitro models that certain MAAs, in particular mycosporine glycine, act as antioxidants in addition to being sunscreens (reviewed in Oren \& GundeCimerman 2007) increases the relevance of the comparison between the accumulation of DMSP and MAAs in the present study. Like DMSP, the occurrence and intracellular concentrations of UV-absorbing compounds varies considerably between microalgal species and strains (Jeffrey et al. 1999). Hence, the seasonal variations observed in DMSPt and MAA concentrations and, in particular, in chlorophyll-specific concentrations of DMSPt and MAAs (Fig. 4) are likely to be driven primarily by taxonomic succession. However, this does not detract from the presumption that the physiological requirements of the phytoplankton to synthesise DMSP, xanthophyll pigments and MAAs are an adaptive response to the environment in which they occur and will be reflected in the seasonal variations in biomass-specific concentrations. Differences between taxa in the photoprotective strategies they employ may explain the variations in specific details between the patterns of DMSPt, Dd + Dt and MAAs observed particularly during summer months (Fig. 4). The dinoflagellate taxa that dominated DMSPt production during stratification of the water column may not have been the taxa that invested most resources in xanthophyll pigment synthesis or that contributed most to MAA production, hence the comparatively low levels of significance between peridinin and Dd $+\mathrm{Dt}$ and MAA (Table 1). Whilst many factors may govern taxonomic succession, energy investment in photoprotective and antioxidant mechanisms, including possibly intracellular DMSP accumulation, xanthophyll pigments and MAAs, may confer a competitive advantage under the stratified, high-light and high-UV environment during summer months in the western English Channel and may, thereby, contribute to the patterns of seasonal taxonomic succession.

The low nutrient concentrations that coincided with stability of the water column and high PAR dose may have contributed to the seasonal pattern in DMSPt concentrations observed at L4. The highly significant inverse relationship between nitrate concentration and log-transformed DMSP/chl a ratio (Fig. 8) indicates that a combination of nitrate limitation and irradiance determined levels of DMSP accumulation by phytoplankton. Several reasons why nitrogen limitation may increase DMSP intracellular accumulation have been proposed. Nutrient limitation of photosynthesis may elevate levels of oxidative stress, boosting the upregulation of antioxidant systems, including possibly DMSP and its breakdown products (Sunda et al. 2007).
Additionally, the capability to synthesise nitrogen-free osmolytes, such as DMSP, may be an advantage to phytoplankton faced with low nitrogen availability (Stefels 2000). However, low nitrate concentrations may not necessarily indicate nutrient limitation. Regenerated ammonium, dissolved organic nitrogen and nitrogen fixation may provide alternative sources of nitrogen during stratified periods in the summer in the western English Channel (Rees et al. 2009). It is possible that inconsistent availability of these alternative nitrogen sources played a part in the highly variable DMSP/chl a ratio observed at low nitrate concentrations at L4 (Fig. 8) and should be considered when interpreting the impact of nitrogen availability in natural phytoplankton communities. Alternatively, the high variability in DMSP/chl a at low nitrate concentrations at L4 may have been a result of taxonomic succession of the major DMSP-producing phytoplankton. In culture, different phytoplankton taxa have shown a wide range of responses in intracellular DMSP concentrations when grown under varied levels of nutrient availability (reviewed in Stefels et al. 2007).

In conclusion, the seasonal study in the western English Channel suggests that the classic 'DMS summer paradox' (Simó \& Pedrós-Alió 1999) of particularly high concentrations of DMS relative to DMSP in shallow, mixed layer conditions typical of summer months may only partially exist in temperate shelf seas. This may be a consequence of the substantial part that taxonomic succession plays in determining DMSP concentrations, and possibly the proportion of DMS produced from DMSP, in these temperate waters. In particular, the 2 peaks in DMSPt during stratified conditions in the summer months were largely the product of 2 different dinoflagellate species, but were distinctly different in terms of the relative DMS to DMSPt concentrations. The chlorophyll-specific accumulation of DMSPt in phytoplankton is closely related to irradiance levels in the temperate shelf seas of the western English Channel. In combination with similar trends observed in the accumulation of xanthophyll pigments that act to prevent photoinhibition and reactive oxygen species production, and in relative concentrations of MAAs, which act as both UV-absorbing compounds and antioxidants, this lends indirect support to the photoprotective role of DMSP. The requirements for this role may be reinforced by low nitrate availability that occurred in parallel to elevated PAR dose and by increased UVB exposure during stratification of the water column. DMSP may function by decreasing the deleterious physiological effects of a combination of too much PAR, damaging UV radiation and nutrient limitation. However, direct physiological evidence of the nature of these roles is still lacking and warrants further study. This, in combination with more specific 
identification of which components of the phytoplankton communities were responsible for DMSP and DMS production, would help explain when, why and how much DMSP and DMS synthesis occurs. Explicit inclusion of DMSP production processes and the controls on that production, including a photophysiological function, may ultimately improve the predictive skill of mechanistic models of DMS biogeochemistry, particularly in temperate waters.

Acknowledgements. We thank the captain and crew of the RV 'Squilla' from which the sampling was carried out, Malcolm Woodward for nutrient analyses and Roger Harris for the phytoplankton abundance data collected as part of the L4Plymouth Time Series. We are grateful to 2 anonymous reviewers and the responsible editor for improvements to an earlier version of this manuscript. This work was supported through the Natural Environment Research Council UK, Grant NE/C51715X/1, and the EU project BASICS Grant EVK3-CT-00078. It also comprises a component of the NERC OCEANS 2025 programme at Plymouth Marine Laboratory.

\section{LITERATURE CITED}

Archer SD (2007) Crucial uncertainties in predicting biological controls of DMS emission. Environ Chem 4:404-405

> Arsalane W, Rousseau B, Duval JC (1994) Influence of the pool size of the xanthophyll cycle on the effects of light stress in a diatom: competition between photoprotection and photoinhibition. Photochem Photobiol 60:237-243

Challenger F, Simpson MI (1948) Studies on biological methylation. A precursor of the dimethyl sulphide evolved by Polysiphonia fastigiata. Dimethyl-2-carboxyethyl sulphonium hydroxide and its salts. J Chem Soc 1948:1591-1597

Charlson RJ, Lovelock JE, Andreae MO, Warren SG (1987) Oceanic phytoplankton, atmospheric sulfur, cloud albedo and climate. Nature 326:655-661

> Dacey JWH, Howse FA, Michaels AF, Wakeham SG (1998) Temporal variability of dimethylsulfide and dimethylsulfoniopropionate in the Sargasso Sea. Deep-Sea Res I 45: 2085-2104

Davidson AT (2006) Effects of ultraviolet radiation on microalgal growth, survival and production. In: Rao S (ed) Algal cultures, analogues of blooms and applications. Science Publishers, Enfield, NH, p 715-768

Grönginer A, Sinha RP, Klisch M, Häder DP (2000) Photoprotective compounds in cyanobacteria, phytoplankton and macro-algae - a database. J Photochem Photobiol B Biol $58: 2-3$

Hannach G, Sigleo AC (1998) Photoinduction of UV-absorbing compounds in six species of marine phytoplankton. Mar Ecol Prog Ser 174:207-222

Holligan PM, Harbour DS (1977) The vertical distribution and succession of phytoplankton in the western English Channel in 1975 and 1976. J Mar Biol Assoc UK 57:1075-1093

Jeffrey SW, Wright SW (2006) Photosynthetic pigments in marine microalgae: insights from cultures and the sea. In: Rao S (ed) Algal cultures, analogues of blooms and applications. Science Publishers, Enfield, NH, p 33-90

Jeffrey SW, Mantoura RFC, Bjørnland T (1997) Data for the identification of 47 key phytoplankton pigments. In: Jeffrey SW, Mantoura RFC, Wright SW (eds) Phytoplankton pigments in oceanography: guidelines to modern methods. UNESCO Publishing, Paris, p 449-559
Jeffrey SW, MacTavish HS, Dunlap WC, Vesk M, Groenewoud K (1999) Occurrence of UVA- and UVB-absorbing compounds in 152 species (206 strains) of marine microalgae. Mar Ecol Prog Ser 189:35-51

Kara AB, Rochford PA, Hurlburt HL (2000) An optimal definition for mixed layer depth. J Geophys Res 105: 16803-16 821

Keller MD, Bellows WK, Guillard RRL (1989) Dimethyl sulfide production in marine-phytoplankton. In: Saltzman ES, Cooper WJ (eds) Biogenic sulfur in the environment. American Chemical Society, Washington, DC, p 167-182

Keller MD, Kiene RP, Matrai PA, Bellows WK (1999) Production of glycine betaine and dimethylsulphoniopropionate in marine phytoplankton. II. N-limited chemostat cultures. Mar Biol 135:249-257

$>$ Kieber DJ, Jiao J, Kiene RP, Bates TS (1996) Impact of dimethylsulfide photochemistry on methyl sulfur cycling in the equatorial Pacific Ocean. J Geophys Res 101(C2): 3715-3722

Kiene RP, Slezak D (2006) Low dissolved DMSP concentrations in seawater revealed by small-volume gravity filtration and dialysis sampling. Limnol Oceanogr Methods 4: 80-95

Kirst GO (1996) Osmotic adjustment in phytoplankton and macroalgae In: Kiene RP, Visscher PT, Keller MD, Kirst GO (eds) Biological and environmental chemistry of DMSP and related sulphonium compounds. Plenum Press, New York, NY, p 121-129

- Kwint RLJ, Kramer KJM (1996) Annual cycle of the production and fate of DMS and DMSP in a marine coastal system. Mar Ecol Prog Ser 134:217-224

Lavaud J, Strzepek RF, Kroth P (2007) Photoprotection capacity differs among diatoms: possible consequences on the spatial distribution of diatoms related to fluctuations in the underwater light climate. Limnol Oceanogr 52:1188-1194

> Leck C, Bigg EK (2005) Source and evolution of the marine aerosol-A new perspective. Geophys Res Lett 32:L19803 doi:10.1029/2005GL023651

> Leck C, Larsson U, Bagender E, Johansson S, Hajdu S (1990) Dimethyl sulfide in the Baltic Sea: annual variability in relation to biological activity. J Geophys Res 95: 3353-3364

> Lefèvre M, Vézina A, Levasseur M, Dacey JWH (2002) A model of dimethylsulfide dynamics for the subtropical North Atlantic. Deep-Sea Res I 49:2221-2239

Llewellyn CA, Harbour DS (2003) A temporal study of mycosporine-like amino acids in surface water phytoplankton from the English Channel and correlation with solar radiation. J Mar Biol Assoc UK 83:1-9

Michaud S, Levasseur M, Cantin G (2007) Seasonal variations in dimethylsulfoniopropionate and dimethylsulfide concentrations in relation to the plankton community in the St Lawrence Estuary. Estuar Coast Shelf Sci 71:741-750

> Neale PJ, Banazak AT, Jarriel CR (1998) Ultraviolet sunscreens in Gymnodinium sanguineum (Dinophyceae): mycosporine-like amino acids protect against inhibition of photosynthesis. J Phycol 34:928-938

Niki T, Kunugi M, Otsuki A (2000) DMSP-lyase activity in five marine phytoplankton species: its potential importance in DMS production. Mar Biol 136:759-764

O'Dowd CD, Jimenez JL, Bahreini R, Flagan RC and others (2002) Marine aerosol formation from biogenic iodine emissions. Nature 417:632-636

> Oren A, Gunde-Cimerman N (2007) Mycosporines and mycosporine-like amino acids: UV protectants or multipurpose secondary metabolites. FEMS Microbiol Lett 269: 1-10 
Rees AP, Gilbert JA, Kelly-Gerreyn BA (2009) Nitrogen fixation in the western English Channel (NE Atlantic Ocean). Mar Ecol Prog Ser 374:7-12

Shaw GE (1983) Bio-controlled thermostasis involving the sulphur cycle. Clim Change 5:297-303

Simó R, Pedrós-Alió C (1999) Role of vertical mixing in controlling the oceanic production of dimethyl sulphide. Nature 402:396-399

Slezak D, Herndl GJ (2003) Effects of ultraviolet and visible radiation on the cellular concentration of dimethylsulfoniopropionate (DMSP) in Emiliania huxleyi (strain L). Mar Ecol Prog Ser 246:61-71

Slezak D, Brugger A, Herndl GJ (2001) Impact of solar radiation on the biological removal of dimethylsulfoniopropionate and dimethylsulfide in marine surface waters. Aquat Microb Ecol 25:87-97

Stefels J (2000) Physiological aspects of the production and conversion of DMSP in marine algae and higher plants. J Sea Res 43:181-197

> Stefels J, van Boekel WHM (1993) Production of DMS from dissolved DMSP in axenic cultures of the marine phytoplankton species Phaeocystis sp. Mar Ecol Prog Ser 97: 11-18

Stefels J, Steinke M, Turner S, Malin G, Belviso S (2007) Environmental constraints on the production and removal of the climatically active gas dimethylsulphide (DMS) and implications for ecosystem modelling. Biogeochemistry 83:245-275

Sunda WG, Hardison DR (2008) Contrasting seasonal patterns in dimethylsulfide, dimethylsulfoniopropionate, and chlorophyll $a$ in a shallow North Carolina estuary and the Sargasso Sea. Aquat Microb Ecol 53:281-294

Sunda W(G), Kieber DJ, Kiene RP, Huntsman S (2002) An antioxidant function for DMSP and DMS in marine algae. Nature 418:317-320

Sunda WG, Hardison DR, Kiene RP, Bucciarelli E, Harada H (2007) The effect of nitrogen limitation on cellular DMSP

Editorial responsibility: Ronald Kiene,

Mobile, Alabama, USA and DMS release in marine phytoplankton: climate feedback implications. Aquat Sci 69:341-351

Tartarotti B, Sommaruga R (2002) The effect of different methanol concentrations and temperatures on the extraction of mycosporine-like amino acids (MAAs) in algae and zooplankton. Arch Hydrobiol 154:691-703

> Toole DA, Siegel DA (2004) Light-driven cycling of dimethylsulfide (DMS) in the Sargasso Sea: closing the loop. Geophys Res Lett 31:L09308

Toole DA, Slezak D, Kiene RP, Kieber DJ, Siegel DA (2006) Effects of solar radiation on dimethylsulfide cycling in the western Atlantic Ocean. Deep-Sea Res I 53:136-153

Toole DA, Siegel DA, Doney SC (2008) A light-driven, onedimensional dimethylsulfide biogeochemical cycling model for the Sargasso Sea. J Geophys Res 113:G02009 doi:10.1029/2007JG000426

Vallina SM, Simó R (2007) Strong relationship between DMS and the solar radiation dose over the global surface ocean. Science 315:506-508

Vallina SM, Simó R, Anderson TR, Gabric A, Cropp R, Pacheco JM (2008) A dynamic model of oceanic sulfur (DMOS) applied to the Sargasso Sea. J Geophys Res Biogeosci 113:G01009 doi:10.1029/2007JG000415

Van Rijssel M, Buma AGJ (2002) UV radiation induced stress does not affect DMSP synthesis in the marine prymnesiophyte Emiliania huxleyi. Aquat Microb Ecol 28:167-174

Vila-Costa M, Kiene RP, Simó R (2008) Seasonal variability of the dynamics of dimethylated sulphur compounds in a coastal northwest Mediterranean site. Limnol Oceanogr 53:198-211

von Glasow R, Crutzen PJ (2004) Model study of multiphase DMS oxidation with a focus on halogens. Atmos Chem Phys 4:589-608

> Woodward EMS, Rees AP (2001) Nutrient distributions in an anticyclonic eddy in the northeast Atlantic Ocean, with reference to nanomolar ammonium concentrations. DeepSea Res II 48:775-793

Submitted: December 22, 2008; Accepted: August 25, 2009 Proofs received from author(s): November 7, 2009 